Varga Csilla Orsolya ${ }^{1}$

\title{
Civil-katonai interakciók az Európai Unió mediterrán térségi tagállamaiban \\ 2. rész
}

\section{Civil-military Interaction in the Mediterranean Area Member States of the European Union}

\author{
Part 2.
}

\begin{abstract}
Absztrakt
A dél-európai országokat és a mediterrán csoportot górcső alá vevő publikáció egy tágabb kutatás eleme, amely az Európai Unió 28 tagállamát vizsgálja. Szük értelemben az Ibériai-félsziget: Spanyolország, Portugália, illetve Franciaország, tágabb értelemben az Appennini-félsziget is vizsgálatom tárgya. Olaszország és Málta, illetve földrajzi térben való érintettsége nyomán: Görögország, Ciprus, Bulgária is helyet kaptak ebben a csoportban. Az országelemzések vizsgálják többek között: a tagállam viszonyát az Európai Unió kül- és biztonság-, illetve védelempolitikájához; a tagállam CIMICorientációját; CIMIC-intézményrendszerét; az Európai Unió vezette katonai müveletben való részvételt (azon belül a CIMIC-relációkat kiemelve); továbbá kitér a CIMIC-képzési, -kiképzési, -felkészitési rendszerre is.

Kulcsszavak: civil-katonai interakció, civil-katonai együttmüködés, kül- és biztonságpolitika, védelempolitika, Európai Unió, müvelet, LOT-összekötő és megfigyelő csoport
\end{abstract}




\section{Abstract}

As part of a broader study of the European Union's 28 Member States, this publication focuses on the Mediterranean group and South European countries of the European Union. I study the Iberian Peninsula: Spain, Portugal and France; but according to the broader sense of the notion, the Appennine Peninsula (Italy) is also part of the study. Furthermore, due to their geographical involvement, Malta, Greece, Cyprus and Bulgaria are also included in this group. Inter alia, country analyses examine the Member States' relationship with the European Union's foreign, security and defence policy; the CIMIC orientation of the given Member State; the institutional system of CIMIC in the country; its participation in the EU-led military operations (including CIMIC relations); and the examination also covers the CIMIC training and education system.

Keywords: civil-military interaction, civil-military cooperation, foreign- and security policy, defence policy, European Union, mission, LOT (Liaison and Observation Team)

\section{Bevezetö}

Kutatómunkám során az Európai Unió tagállamait elemeztem. A Felderítő Szemlében megjelent a Benelux államok és a skandináv államok elemzése. Jelen publikáció a dél-európai országok és mediterrán csoportot veszi górcső alá. Szük értelemben az Ibériai-félsziget: Spanyolország, Portugália, illetve Franciaország tartozna ide, de tágabb értelemben az Appennini-félszigetet is hozzávettem: Olaszország és Málta, illetve földrajzi térben való érintettsége nyomán: Görögország, Ciprus, Bulgária is helyet kaptak ebben a csoportban. Az országelemzések vizsgálják többek között: a tagállam viszonyát az Európai Unió kül- és biztonság-, illetve védelempolitikájához; a tagállam civil-katonai interakciókra vonatkozó orientációját; civil-katonai együttműködésre (CIMIC) vonatkozó intézményrendszerét; az Európai Unió vezette katonai műveletben való részvételt (azon belül a CIMIC-relációkat kiemelve); továbbá kitér a CIMIC-képzési, -kiképzési, -felkészítési rendszerre is. Az első részben Spanyolország, Portugália, Olaszország és Franciaország, a második részben Bulgária, Görögország, Ciprus és Málta elemzésem tárgya.

A dél-európai és mediterrán térség kihívásai sokrétüek: többek között a tengeri jelenlét és védelem vagy Afrika felől jelentkező migrációs veszélyek. A mediterrán térség országai pedig egyes esetekben eltérő értékekkel, érdekekkel is rendelkeznek. Alapvetően azonban a közös kezdeményezés és részvétel, a regionális együttműködés, csakúgy, mint a balti vagy skandináv államokra szintén jellemző.

Az EUROMARFOR² - Olaszország, Spanyolország, Franciaország, Portugália részvételével - egy, a petersbergi feladatok végrehajtására alkotott egyesülés, amely békefenntartó, békekikényszerítő, humanitárius feladatokat, illetve tengeri ellenőrzési célokat valósít meg. A szervezetet 1995-ben hozták létre, első művelete 
2002-ben (Operation Coherent Behaviour)3 az EU későbbi haditengerészeti műveleteinek (EUNAVFOR Atalanta, EUNAVFOR MED Sophia) fontos állomása. Az első részben vizsgált országok: Franciaország, Olaszország, Portugália, Spanyolország. A második részben vizsgált országok: Bulgária, Ciprus, Görögország, Málta.

\section{Bulgária}

Bulgária, tágan értelmezve dél-európai, ugyanakkor a balkáni régióhoz tartozó ország is. A mediterrán térség mellett a Balkán-félsziget területét érintő kérdésekben is hangsúlyos szerepet vállal. ${ }^{4}$ Bulgária már az európai uniós csatlakozása előtt is elkötelezett volt közös kül- és biztonság-, illetve védelempolitikát illetően, ahol aktív politikai dialógust és aktív missziós részvételt tanúsít.

Bulgária 2007-ben csatlakozott az Európai Unióhoz. Hadereje: 31500 fő aktív állományú és 303000 fő tartalékosból áll. Az EUFOR Althea és az EUNAVFOR Atalanta műveleteiben vesz részt. ${ }^{5}$ Az EUFOR Altheában 120 fös bolgár kontingens vesz részt, amely egyrészt a szarajevói Camp Butmir tábor fegyveres őrségét adja, másrészt az EUFOR „szeme és füleként"6 müködő összekötő és megfigyelő csoportokat, úgynevezett LOT-házakat ${ }^{7}$ is üzemeltet, amely a civil-katonai együttmüködésben jelentős intézményt jelent. ${ }^{8}$

"A célokat, érdekeket a szocialisták (Bulgarian Socialist Party, BSP vagy az úgynevezett Centenarian) mindvégig támogatták. A demokraták (Union of Democratic Forces, UDF) szintén, minden területen támogatták a CFSP/ESDP céljait és elképzeléseit, főként a térség biztonságának előmozdítását, a szomszédságpolitikát emelve ki annak hangsúlyos elemei közül. A szabadságpárt (Movement of Right and Freedom, MRF), az aktív szerepvállalás, főként a béketámogató műveletek fontossága mellett foglaltak állást, támogatva ezzel az Európai Unió közös kül- és biztonságpolitikáját és annak célkitűzéseit. Az ország korábbi missziós tapasztalatai pedig megalapozták az EU-vezette műveletekben való aktív és hatékony részvételt." ${ }^{p}$

A migrációt illetően, Bulgária az EU külső határához tartozó tagállam, így a migráció okozta kihívásokkal fokozottan szembe kell néznie. A környező, EU-n kívüli térség jó része pedig instabil régió, amely további feladatok elé állítja az országot. ${ }^{10}$

A közvélemény is osztja azt a véleményt, hogy a migráció, illetve a külső határok felöl ezzel együtt érkező más veszélyek is a közös védelempolitika erősitését kívánják.

\footnotetext{
EUROMARFOR (EMF) - a non-standing, pre-structured, multinational maritime force, born on 15 May 1995.

Vanelin Tsachevsky: Bulgaria's EU membership: the adaptation to the new status is not over. Sofia, Pan-European Institute, 2010. 11.

5 Mission and Operations. Ministry of Defense of the Republic of Bulgaria; European Union Naval Force Operation Atalanta (EU Navfor Atalanta) in the Indian Ocean and the Gulf of Aden; Participation of Bulgarian Military Personnel in Bosnia and Herzegovina (SFOR/ALTHEA).

EUFOR LOTs - your neighbors. EUFOR, 11.

LOT - Liaison and Observation Team, összekötő és megfigyelö csoport.

8 Mission and Operations. Ministry of Defense of the Republic of Bulgaria; Plamen Yordanov: Bulgaria in European Security and Defence Policy. Carlisle, Us Army War College, 2013. 18.

9 Georgi Mitov: Basic views of CFSP/ESDP in Bulgaria. Priorities for the government in CFSP; key issues for Bulgaria. CFSP Watch 2003, Sofia, BECSA.

10 Strategy Project International Fellow. Yordanov (2013) i. m.
} 
A közvéleménynek nagy bizalma van a bolgár haderőt és annak EU-részvételét illetően egyaránt. ${ }^{11}$

A CIMIC-et illetően, ahogy a fehér könyvben is megtalálható, Bulgária a CIMIC és PSYOPS területét együttesen kezeli, arra külön, nemzeti egysége van a szárazföldi haderőnemen belül. Emellett, a müveleti területeken az ország CIMIC-központokat üzemeltet (Bosznia-Hercegovinában LOT-házat). A képzés, kiképzés, felkészítés nemzeti szinten a Georgi Sava Rakovski Nemzetvédelmi Akadémián ${ }^{12}$ és a Nemzeti Katonai Egyetemen történik, a nemzetközi képzés részben szintén a G. S. Rakovski Akadémián, illetve az EU/NATO akkreditált CIMIC-felkészítések keretében történik. A funkcionális specialisták, azaz civilek részére szintén van lehetőség a katonai akadémián történő felkészítésre, amelyek időtartama részben az előképzettség függvénye.

A CIMIC-képességek megfelelnek az EU-/NATO-követelményrendszernek, de már folyik egy szélesebb körű CIMIC-PSYOPS képesség- és intézményrendszer kialakítása is, amely szélesebb földrajzi területen, az információgyűjtés, rendszerezés területét is magában foglaló tevékenységi kör ellátására is alkalmas. Az információgyüjtés, a müveleti területen müködtetett CIMIC-központok esetében is kulcsfontosságú feladat. ${ }^{13}$

\section{Ciprus}

Ciprus földrajzilag, kulturális, történelmi és politikai tekintetben is Európa részének tekinthetö, a kontinenshez való viszonya azonban sok tekintetben különleges, ahogy maga az ország is. Egyenlő távolságra van Afrikától és Európától, illetve a KözelKelettől is. Kulturális öröksége alapján görög, mégsem volt soha része Görögországnak. Évszázadokig volt ellenben a török birodalom része. A törökök aránya mégis kisebbséget alkot.

A közös kül- és biztonságpolitikához való viszony: Ciprus az EU-t az emberi jogok, a demokrácia védelmezőjeként, a biztonság megteremtőjeként, erős intézménynek látja. A sziget megosztott állapotban történő csatlakozása mellett is, az EU-t képesnek látta a ciprusi válság megoldására. E célok azonban csak szoros együttmüködéssel érhetőek el. Fontos, hogy az EU egységes hangon megszólalva támogassa a ciprusi újraegyesítést. ${ }^{14}$ 2016-ban már csak karnyújtásnyira volt, de végül mégsem történt meg az egyesítés, ötnapi tanácskozás után a tárgyalások ismét eredménytelenül zárultak. 2017-ben, illetve 2019-ben is elakadtak az egyesítési tárgyalások. ${ }^{15}$

„Az újraegyesített, föderálisan múködő Cipruson még mindig kérdés, hol húzódjon a török és görög lakosságot elválasztó határ. A vitát az okozza, hogy a törökök vannak kisebbségben, mégis a görögök szerint nagyobb területen élnek, mint amely lélekszámuk alapján járna nekik. A görög lakosság körülbelül 850000 fö, a török 300000 fő. A görögök lakta rész gazdaságilag is erősebb. Sőt, a török lakosság is két részre osztható,

\footnotetext{
Yantsislav Yanakiev: Views of the Bulgarian Public on Security, Defence and Military. Geneva, DCAF, 2000. 254-264.

G. S. Rakovski National Defense Academy.

White Paper on Defence and the Armed Forces of the Republic of Bulgaria. Sofia, 2010.; Mitov (2003) i. m.

Angelos Sepos: Europeanization of Cyprus. London, Palgrave Mcmillan, 2008. 34-45., 59-76., 120-134.

A ciprusi görögök és ciprusi törökök vajon képesek lesznek-e végül közös nevezöre jutni? TRT, 2019.
} 
az évszázadok óta ott élő török lakossággal szemben ott áll, körülbelül 140-160 000 fő bevándorló, akik az elmúlt 40 évben telepedtek le, őket illegális migránsnak tekintik."16

Ezenfelül még egy kérdés vár megoldásra: a katonai támaszpontoké, hiszen Törökország 30 ezer fös kontingenst állomásoztat Cipruson, míg Nagy-Britannia kettö, összesen 3000 fös támaszpontot tart fenn a déli parton..$^{17} \mathrm{~A}$ török kontingens kvázi mindenkit zavar, ugyanakkor: a brit támaszpontok ellen nincs kifogása a politikusoknak, sem a közvéleménynek. Szerencsésen indult a helyzet, hiszen a görög ciprusi és török kollégája személyében, poszton lévő elnök is hajlandó volt a "kompromisszumra", ám az mégsem jött létre. A migránskérdésben is érintett Ciprus megállapodott Törökországgal, hogy az visszaveszi az illegális bevándorlókat, és közösen lépnek fel az embercsempészet ellen is. Törökország és az EU között létrejött megállapodás szerint: Törökország jelentős anyagi segítséget kap, ha eltörli a schengeni turistavízumot, és együttmúködik a ciprusi rendezés támogatásában. Ebbe a katonai kontingensének fokozatos kivonása is beletartozik. Az Európai Uniónak is gondot jelent, hogy a déli határán egy, kvázi törvénytelen, demilitarizált zóna áll, de végül ezt a kérdést sem sikerült megoldani. Nem mellékes kérdésként pedig újra felvetődött, hogy hivatalos EU-nyelv lesz-e a török, hiszen, az uniós polgárokat megilleti, hogy hazájuk hivatalos nyelvén férjenek hozzá az EU dokumentumaihoz, ez a kérdés azonban az uniós tagállamok kezében, s nem az EU Parlament döntési körében születhetne meg.

Több fenti kérdésben Bulgária is érdekelt, hiszen területén félmilliós lélekszámú török lakosság él. Ciprus egyetért az ESDP céljaival, megvalósításában tevékenyen részt vesz. A rendőri missziókhoz is hozzájárul. Az ESDP-t nem csak delegált személyzettel és felajánlásokkal, elvben is messzemenőkig támogatja, hiszen önmagát az EU elöretolt bástyájaként határozza meg. A mediterrán politika és dimenzió fejlesztésében is érdekelt, azt szintén támogatja. A CFSP Ciprusnak egy olyan lehetőséget kínált, amelynek során a nagy államok függőségéből kikerülve, önállóbb kül- és biztonságpolitikai nézeteit érvényre juttathatta.

A közös kül- és biztonságpolitika keretében indított, katonai missziók közül az EUTM Mali (2 fö) és az EUNAVFOR Szomália műveletekben vesz részt. ${ }^{18}$ Hadereje 12 ezer fös, sorozott hadsereg és 50 ezer fö önkéntes..$^{19}$ 2016-ban az ARGONAUT nevet viselő CIMIC nemzetközi gyakorlat Ciprusban zajlott, ${ }^{20}$ amely a nemzeti ESTIA-terv bevezetésével áll szinkronban. A gyakorlat során a cél nagyszámú civil kimentése volt, a Közel-Keletröl a Ciprus területén található fogadó állomásokra. A szcenárió során a haditengerészeti erők és a légierő, a szárazföldi erőkkel kooperálva, nagyszámú civilt mentett ki nyílt tengeri vizekröl. A gyakorlaton Görögország, Olaszország, Magyarország, az Egyesült Királyság, illetve Izrael és az Amerikai Egyesült Államok vettek részt. A központi koordinációt a larnacai JRCC (Joint Rescue Coordination Centre) látta el.

\footnotetext{
Kugyela Tamás: Karnyújtásnyira a ciprusi újraegyesités. Index, 2016; Megfeneklett Ciprus újraegyesitése. Origo.

Darren Loucaides: Why Are There Still British Military Bases in Cyprus? New Internationalist, 2017.

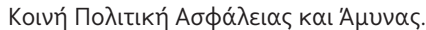

The Military Balance 2019. London, IISS, 2019. 96.

Argonaut concludes successfully in Cyprus. Parikiaki.
} 


\section{Görögország}

Görögország csatlakozását az Európai Unióhoz nem kísérte heves nemzeti vita, sem a politika, sem a közvélemény oldaláról. Csatlakozása talán túl korai időpontban történt, amelynek egyes következményei várhatóak voltak, és ezt a később felmerült kilépésének kilátásba helyezése meg is erősítette. 2010-ben Görögország eurózónás fizetésképtelenné válásakor a Grexit (Greek exit) felmerülése komoly vitákat gerjesztett, hiszen az eurózónából való kilépés az EU-tagság megtartásával nem lehetetlen, de éket verhetett volna bizonyos vezető politikai országok közé, illetve Görögország és az EU-tagállamok közé.

Végül 2015-ben görög kormányváltás, népszavazás és az EU úgynevezett „harmadik programjának" köszönhetően mentőcsomagot biztosítottak az ország számára, egyben „tűzfalat” is emelve ezzel, hogy a hasonló kockázatnak kitett országokra a konfliktus ne terjedhessen tovább. ${ }^{21}$ A migrációs politika európai uniós szintü kezelése a védelempolitika, a közös védelempolitika része, a 2016. decemberi EU-csúcs egyik központi témája. ${ }^{22}$

Az EU-védelempolitikával magas szinten foglalkozó csoportok ülésére legutóbb, ezt megelőzően öt évvel került sor, így a 2016-os csúcs, a védelempolitika megerősítését célzó intézkedései meghatározóak lettek a következő években is. A 2013-as, a fegyverkezési és haditechnikai beruházások csökkentését, létszámleépítéseket, összevonásokat tartalmazó úgynevezett „GroKo"23 programja már előrevetítette a költséghatékonyság irányába mutató közös lépéseket, így azok hatékonyabban folytatódhatnának tovább.

„A gazdasági és migrációs válsággal egy időben, a görög euroszkepticizmus ugyan felütötte a fejét, és a görögök megítélése a világban egy kicsit negatív irányba mozdult el, a nemzetközi szervezetekkel történő együttmüködések idővel ezen az átmeneti problémán is átsegítették az országot."24

Hadereje: 93500 fős aktív állományból (ebből 48500 fő hivatásos, 45 ezer fő sorozott), illetve 220500 fő tartalékosból áll. ${ }^{25}$ Az ESDP (European Security and Defence Policy) rendőri és katonai elemeit is támogatja, főként a konfliktus megelőző akciókban vállal nagy szerepet a balkáni térség, illetve a mediterrán térség területén. Az elmúlt időszakban az EU katonai misszióiban csak néhány fővel képviseltette magát, inkább a rendőri missziókban jelentős a részvétele. Az EUFOR Althea müveletben egy fö, az EUTM Maliban két fő görög katona vett részt (2016-2019). ${ }^{26}$

CIMIC görög részvétel ezekben a müveletekben nem zajlik. Görögország nemzetközi oktatási-képzési központot üzemeltet Kilkis településen. Az MPSOTC (Multinational Peace Support Operation Training Center) ${ }^{27}$ a világ 11 legnagyobb ilyen jellegű központjának az egyike, az EU-kontingensek müveletre történő képzését, kiképzését végzi, többek

\footnotetext{
Sarkadi-Szabó Kornél: Görög euró: a kilépés buktatói. Shark Vision, 2015. Görögország. Kitekintő.

EU-csúcs: A migráció és a védelempolitika a középpontban. Kitekintö.

Közös védelempolitikán rágódik az EU. Kitekintö.

24 Anna Elisabeth Tsakona: Greece: From Europhile to Eurosceptic, is EU's negative image here to say? In Greek Foreign Policy, Global Trends and Challenges. Athens, Hellenic Center for European Studies (EKEM), 2013. 14-21.

25 The Military Balance 2019. (2019) i. m. 116.

26 Uo. 116

27 Welcome. MPSOTC.
} 
között, CIMIC területén is. A nemzeti felkészítés az Európai Integrációs és Politikai Intézetben is jelentős. A független intézmény tanulmányokkal, oktatás, képzés, továbbképzés révén segíti a hadtudományt, azon belül a CIMIC-jellegü témákkal is foglalkozik. ${ }^{28}$ Görögország jelenleg nem végez CIMIC-tevékenységet EU-műveletekben, EU katonai múveleti jelenléte is mindösszesen néhány fő. Görögország nemzeti CIMICdoktrínája a fegyveres erők, főként a szárazföldi haderőnem, sokrétü tevékenységének szerves részét képezi.

Szoros az együttműködés az egészségügyi, katasztrófaelhárítási, a légierő mentőhelikopter-egységeivel, ugyanakkor a logisztikai egységekkel (humanitárius segítségnyújtás keretében szállított segélyek), nemzetközi szervezetekkel, akár helyszín biztosítása, szállítás, tolmácsolás vagy müszaki segítségnyújtás a cél. A CIMICképességek az emberi erőforrások mellett eszközök, jármúvek biztosítását egyaránt jelentik. A görög haderő CIMIC-egységei tehát nem önálló múveleti egységek, mindig valamely más egységgel együtt látják el tevékenységüket.

\section{Málta}

A máltai külpolitika egyik kiemelt területe a nemzetközi szervezetekben történő tevékeny szerepvállalás. Málta mindig erőteljesen hallatta a hangját, kis méretéhez képest, akár az EBESZ- (Európai Biztonsági és Együttműködési Szervezet) előfutár EBEÉ, akár nemzetközi haditengerészeti együttmüködésről volt szó (például UNCLOS), ${ }^{29}$ azaz támogatja az olyan nemzetközi közösségi megmozdulásokat, amelyek során a béke és biztonság felelősségének a kérdését együttesen vállalják a szereplők. A biztonságáról folytatott párbeszédek és fórumok jeles képviselője, és szorgalmazza a mediterrán térség stabilitási paktumának kidolgozását is.

A semlegességet a kormány és az ellenzék is sajátosan, de rugalmasan kezeli, de saját, politikai érdekeik mellett az ország érdekeit is szem előtt tartva hangsúlyozzák az unió formálódó, folyamatosan alakuló védelmi dimenziójához igazítva azt. Egyfajta modell is Málta, amely megmutatja, hogy kis ország is lehet sikeres nemzetközi színtéren. Az EU közös védelempolitikáját illetően, a többi, semleges, EU-tagországhoz hasonlóan az aktív semlegesség híve. Az EU-ban itt a legmagasabb azon menekültek aránya, akik úgynevezett humanitárius státuszt kapnak. Az elmúlt években a migrációs politika és a státuszok kiadása sokat szigorodott az országban, és közös EU-megoldást szorgalmaz, többek között észak-afrikai fogadó táborokat. Málta hadereje meglehetősen kis létszámú: 1950 fő az aktív állomány és 180 fő a tartalékos állomány. A missziós részvételről minden esetben, egyedi esetként a máltai kormány dönt. ${ }^{30}$

Az EUNAVFOR Atalanta múveletben Málta 2009-2013 ${ }^{31}$ között aktívan részt vett haditengerészeti állományával a WFP program keretében, illetve az aktív jelenlét és ellenőrzés területén. A művelet sikerével a kalóztámadások száma minimálisra redukálódott, így már Málta sem vesz részt nagyszámú erővel a müvelet további

28 The Institute.

29 Oceans and Law of the Sea. Division for Ocean Affairs and the Law of the Sea. 1982.

30 The Military Balance 2019. (2019) i. m. 128.

31 European Union Naval Force (EU NAVFOR) Somalia - Operation ATALANTA. Armed Forces of Malta. 
szakaszában. Az EUTM (European Union Training Mission) Szomália műveletben az ír kontingenssel együtt 2009-ben kiképzési feladatokat látott el Málta a Mihanga-táborban (Uganda területén). A hatfős instruktorcsapat sikeres munkát végzett az írekkel közösen, 2010-ben ezért újra vállalták ezt a feladatot. 2010-ben három tiszthelyettesi rangú kiképző hat hónapos szolgálat után fejezte be feladatát. ${ }^{32}$

\section{6. Összegzés}

A komparatív elemzés feltárja a tagállamok erősségeit, gyengeségeit, lehetőségeit és azokat az akadályokat is, amelyek leküzdése érdekében a jövőben lépéseket kell tenniük. A tagállamok elemzése és az egyező paraméterek összehasonlítása mentén a lehetséges, várható tendenciák és fejlődési lehetőségek, illetve a hazánkkal azonos méretü, gazdasági, katonai potenciállal rendelkező országok esetében levonható konzekvenciák a kutatás során összegzett eredmények alapján hasznosíthatók.

A civil-katonai orientációt tekintve Málta követ leginkább nemzeti sajátosságokat. A képzés, kiképzés több körös, nemzeti és nemzetközi intézményekben történik (Görögország a legnagyobb ilyen képzési intézmények egyikét müködteti), a nemzeti intézmények tekintetében azonban eltérés mutatkozik, hogy az független vagy beágyazott (esetleg osztozik valamely más területtel, általában a CIMIC- a PSYOPS-területtel).

A létszámot tekintve a tagállamok hadereje nagy szórást mutat, föként az aktív és tartalékos állomány egymáshoz viszonyított arányát figyelembe véve. Bulgária a 300 ezer fős tartalékos állománnyal messze kiemelkedik. Magyarországon az aktív létszám 27800 fö, a tartalékos létszám 20 ezer fő.

Az EU katonai műveleteiben való részvétel során természetes, hogy a nagy kiterjedésü tengerparttal rendelkező országok, az EUNAVFOR haditengerészeti műveletekben nagy szerepet vállalnak. A cikkben szereplö tagállamok közül Görögország rendelkezik a leghosszabb partokkal. ${ }^{33}$ Kisebb országok, mint Málta, kis létszámmal vettek részt az EUNAVFOR-múveletekben, vagy kontingenseiket az utóbbi években kivonták. Magyarország az EUNAVFOR-műveletekben nem vesz részt. ${ }^{34}$

Magyarország mint a schengeni határokat őrző tagállam esetében, a 2015-ben tömeges migráció okozta nyomás alatt a Magyar Honvédség feladatai is bővültek, feladatai, szerepe, helyzete - különös tekintettel az Európai Unió schengeni közösségi kódex 2. cikk 2. pontjának megfelelően - is módosult. ${ }^{35}$

A hadtudományi kutatások prioritásai között is szerepel a migráció okozta veszélyhelyzet és az ebből eredő megoldási javaslatok vizsgálata, a haderőstruktúra és reagáló erők létrehozása. ${ }^{36} \mathrm{~A}$ tagállamok esetében, a vizsgált elemek, mint a haderőstruktúra, illetve megoldási javaslatok összevetése, a tagállamok viszonya az Európai

32 European Union Training Mission Somalia (EUTM SOMALIA). Armed Forces of Malta; Laiviera, Nestor: AFM military instructors training Somali troops. Maltatoday, 2011.

33 Coastline lengths.

34 The Military Balance 2019. (2019) i. m. 117.

35 Farkas Ádám et alii: A Magyar Honvédség feladatai, szerepének és helyzetének jogi aspektusai a tömeges migráció kapcsán. In Tálas Péter (szerk.): Magyarország és a 2015-ös európai migárciós válság. Budapest, Dialóg Campus, 2017. 159-178.

36 Boda József et alii: A hadtudományi kutatási irányok, prioritások és témakörök. Államtudományi Mühelytanulmányok, (2016), 16. 1-23. 
Unió biztonság- és védelempolitikához, komparativitása révén ezeket a hadtudományi prioritásokat szolgálja.

\section{Felhasznált irodalom}

Boda József - Boldizsár Gábor - Kovács László-Orosz Zoltán-Padányi József - Resperger István - Szenes Zoltán: A hadtudományi kutatási irányok, prioritások és témakörök. Államtudományi Mühelytanulmányok, (2016), 16. 1-23. Elérhető: www. med.u-szeged.hu/download.php?docID=90702 (A letöltés dátuma: 2020. 05. 02.)

Farkas Ádám - Horváth Tibor - Padányi József - Petruska Ferenc: A Magyar Honvédség feladatai, szerepének és helyzetének jogi aspektusai a tömeges migráció kapcsán. In Tálas Péter (szerk.): Magyarország és a 2015-ös európai migárciós válság. Budapest, Dialóg Campus, 2017. 159-178. Elérhető: https://fejlesztesiprogramok.uni-nke.hu/ document/fejlesztesiprogramok-uni-nke-hu/Magyarorszag_es_a_2015_os_migracios_valsag_web.pdf (A letöltés dátuma: 2020. 05. 02.)

Plamen, Yordanov: Bulgaria in European Security and Defence Policy. Carlisle, Us Army War College, 2013. Elérhető: www.dtic.mil/cgi-bin/GetTRDoc?AD=ADA589902 (A letöltés dátuma: 2018. 12. 10.)

Sepos, Angelos: Europeanization of Cyprus. London, Palgrave Mcmillan, 2008. DOI: https://doi.org/10.1057/9780230229822

The Military Balance 2019. London, IISS, 2019.

Tsachevsky, Vanelin: Bulgaria's EU membership: the adaptation to the new status is not over. Sofia, Pan-European Institute, 2010. Elérhetö: www.utu.fi/fi/yksikot/ tse/yksikot/PEl/raportit-ja-tietopaketit/Documents/Tsachevsky_netti_final.pdf (A letöltés dátuma: 2019. 12. 10.)

Tsakona, Anna Elisabeth: Greece: From Europhile to Eurosceptic, is EU's negative image here to say? In Greek Foreign Policy, Global Trends and Challenges. Athens, Hellenic Center for European Studies (EKEM), 2013.

White Paper on Defence and the Armed Forces of the Republic of Bulgaria. Sofia, 2010. Elérhető: www.eda.europa.eu/docs/default-source/documents/white-paper-bulgaria_eng_2009-10.pdf (A letöltés dátuma: 2019. 12. 10.)

Yanakiev, Yantsislav: Views of the Bulgarian Public on Security, Defence and Military. Geneva, DCAF, 2000.

\section{Internetes források}

A ciprusi görögök és ciprusi törökök vajon képesek lesznek-e végül közös nevezöre jutni? TRT, 2019. Elérhető: www.trt.net.tr/magyar/tersegi-hirek/2019/07/30/a-ciprusi-gorogok-es-ciprusi-torokok-vajon-kepesek-lesznek-e-vegul-kozos-nevezore-jutni-1244445 (A letöltés dátuma: 2020. 03. 01.)

Argonaut concludes successfully in Cyprus. Parikiaki, 2016. Elérhető: www.parikiaki. com/2016/06/argonaut-concludes-successfully-in-cyprus/ (A letöltés dátuma: 2021. 01. 09.) 
Coastline lengths. Elérhetö: http://world.bymap.org/Coastlines.html (A letöltés dátuma: 2020. 04. 30.)

EUFOR LOTs-yourneighbors. EUFOR, 2016. Elérhető: www.euforbih.org/eufor/images/ pdfs/Teme/2016/201607_eng.pdf (A letöltés dátuma: 2020. 04. 30.)

EUROMARFOR. Elérhető: www.euromarfor.org/ (A letöltés dátuma: 2020. 04. 17.)

EUROMARFOR (EMF) - a non-standing, pre-structured, multinational maritime force, born on 15 May 1995. Elérhető: www.euromarfor.org/overview/3 (A letöltés dátuma: 2020. 04. 17.)

EU-csúcs: A migráció és a védelempolitika a középpontban. Kitekintő, 2016. Elérhető: http://kitekinto.hu/2016/12/14/europai-ugyek/eu-csucs-a-migracio-es-a-vedelempolitika-a-kozeppontban/ (A letöltés dátuma: 2019. 12. 28.)

European Union Naval Force (EU NAVFOR) Somalia - Operation ATALANTA. Armed Forces of Malta. Elérhetö: https://afm.gov.mt/en/operationsanddeployments/ overseas/Pages/EU-Navfor.aspx (A letöltés dátuma: 2021. 01. 09.)

European Union Naval Force Operation Atalanta (EU Navfor Atalanta) in the Indian Ocean and the Gulf of Aden. Elérhetö: www.mod.bg/en/doc/tema/OPERATION_ ATALANTA.pdf (A letöltés dátuma: 2021. 01. 08.)

European Union Training Mission Somalia (EUTM SOMALIA). Armed Forces of Malta. Elérhetö: https://afm.gov.mt/en/operationsanddeployments/overseas/Pages/ EUTM-Somalia.aspx (A letöltés dátuma: 2021. 01. 09.)

G. S. Rakovski National Defense Academy. Elérhetö: http://armf.academia.edu/ (A letöltés dátuma: 2020. 05. 29.)

Görögország. Kitekintő. Elérhető: http://kitekinto.hu/cimke/gorogorszag/ (A letöltés dátuma: 2019. 02. 01.)

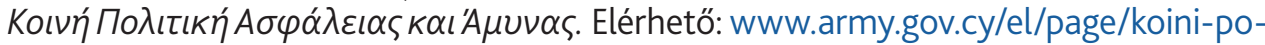
litiki-asfaleias (A letöltés dátuma: 2019. 12. 11.)

Közös védelempolitikán rágódik az EU. Kitekintő, 2013. Elérhető: https://kitekinto. hu/2013/12/19/europai-ugyek/europa20131219kozos_vedelempolitikan_ragodik_az_eu/84667/ (A letöltés dátuma: 2021. 01. 09.)

Kugyela Tamás: Karnyújtásnyira a ciprusi újraegyesítés. Index, 2016. Elérhető: http:// index.hu/kulfold/eurologus/2016/10/29/karnyujtasnyira_a_ciprusi_ujraegyesites/ (A letöltés dátuma: 2019. 11. 12.)

Laiviera, Nestor: AFM military instructors training Somali troops. Maltatoday, 2011. Elérhető: www.maltatoday.com.mt/news/national/8154/afm-military-instructors-training-somali-troops\#.WGyiT_nhDDc (A letöltés dátuma: 2019. 11. 12.)

Loucaides, Darren: Why Are There Still British Military Bases in Cyprus? New Internationalist, 2017. Elérhetö: https://newint.org/features/2017/05/01/caught-in-the-middle (A letöltés dátuma: 2019. 11. 11.)

Malta. EUNAVFOR. Elérhető: http://eunavfor.eu/?s=malta (A letöltés dátuma: 2019. 11. 12.)

Megfeneklett Ciprus újraegyesítése. Origo, 2016. Elérhető: www.origo.hu/nagyvilag/20161122-eredmenytelenul-fejezodtek-be-a-megosztott-ciprus-egyesiteserol-masfel-eve-folyo-targyalasok.html (A letöltés dátuma: 2019. 12. 10.)

Mission and Operations. Ministry of Defense of the Republic of Bulgaria. Elérhető: www. mod.bg/en/tema_MissionsOperations.html (A letöltés dátuma: 2021. 01. 08.) 
Mitov, Georgi: Basic views of CFSP/ESDP in Bulgaria. Priorities for the government in CFSP; key issues for Bulgaria. CFSP Watch 2003, Sofia, BECSA. Elérhető: www.lse. ac.uk/international-relations/assets/documents/efpu/cfsp-annual-reports/2003/ BULGARIA-2003.pdf (A letöltés dátuma: 2021. 01. 09.)

Oceans and Law of the Sea. Division for Ocean Affairs and the Law of the Sea, 1982. Elérhető: www.un.org/depts/los/convention_agreements/texts/unclos/UNCLOSTOC.htm (A letöltés dátuma: 2019. 12. 12.)

Participation of Bulgarian Military Personnel in Bosnia and Herzegovina (SFOR/ALTHEA). Elérhető: www.mod.bg/en/doc/tema/MissionsOperations3.pdf (A letöltés dátuma: 2021. 01. 08.)

Sarkadi-Szabó Kornél: Görög euró: a kilépés buktatói. Shark Vision, 2015. Elérhetö: http:// sharkvision.hu/gorog-euro-a-kilepes-buktatoi/ (A letöltés dátuma: 2019. 01. 03.)

The Institute. Elérhető: https://eeep-en.pspa.uoa.gr/the_institute/ (A letöltés dátuma: 2021. 01. 09.)

Welcome. MPSOTC. Elérhető: https://mpsotc.army.gr/en/welcome (A letöltés dátuma: 2021. 01. 09.) 